\title{
Arthropod-borne infections in travelled dogs in Europe
}

\author{
Dietmar Hamel*,a, Cornelia Silaghi and Kurt Pfister \\ Comparative Tropical Medicine and Parasitology, Veterinary Faculty, Ludwig-Maximilians-Universität München, Leopoldstraße 5, \\ 80802 Munich, Germany
}

Received 12 October 2012, Accepted 27 February 2013, Published online 12 March 2013

\begin{abstract}
Pet animal movement is ever increasing within the European Union and in that context canine vectorborne infections gained a considerable importance. Information on these infections in travelled dogs is nevertheless limited. A first prospective study on vector-borne infections was conducted in 106 dogs travelling from Germany to countries in South and South-East Europe. The dogs were screened prior to and consecutively up to three times after travel by haematological (Giemsa-stained buffy coat smears, Knott's-Test), molecular biological (PCR) as well as serological (IFAT, DiroChek ${ }^{\circledR}$-ELISA) methods for arthropod-borne infections. Seven animals were seropositive for antibodies against Babesia canis sspp., Leishmania spp. and/or Ehrlichia canis prior to travel to Italy, Spain, France, Croatia, Greece, or Hungary. In the consecutive screening after return there was no increase in the number of seropositive dogs. None was positive in direct methods. The mean duration of the stay was 17 days and $51 \%$ of the dogs were prophylactically treated with ectoparasiticidal formulations. Preliminary data from this study on canine vector-borne infections indicate a low risk for infection during a limited single stay in endemic countries.
\end{abstract}

Key words: Vector-borne infections, Travelling dogs, Prophylaxis, Germany.

Résumé - Infections transmises par les arthropodes chez des chiens voyageant en Europe. Les mouvements des animaux de compagnie augmentent constamment dans l'Union européenne et dans ce contexte les infections canines transmises par les vecteurs prennent une importance considérable. Toutefois, les informations sur les infections des chiens qui voyagent sont limitées. Une première étude prospective a été conduite chez 106 chiens voyageant depuis l'Allemagne vers des pays du Sud et du Sud-est de l'Europe. Les chiens ont été testés avant et une à trois fois après le voyage par des tests hématologiques (frottis colorés au Giemsa, teste de Knott), moléculaires (PCR) et sérologiques (IFAT, DiroChek ${ }^{\circledR}$-ELISA) des infections transmises par les vecteurs. Sept animaux étaient séropositifs pour les anticorps contre Babesia canis sspp., Leishmania spp. et/ou Ehrlichia canis avant leur voyage vers l'Italie, l'Espagne, la France, la Croatie, la Grèce ou la Hongrie. Dans les tests après leur retour il n'y avait pas d'augmentation du nombre de chiens séropositifs. Aucun n'a été positif par des méthodes directes. La durée moyenne du séjour était de 17 jours et $51 \%$ des chiens ont été traités de manière prophylactique par des produits anti-ectoparasites. Les données préliminaires de cette étude sur les infections transmises par les vecteurs indiquent un faible risque d'infection pour un séjour unique de durée limitée en pays endémique.

\section{Introduction}

Canine vector-borne infections are a steadily increasing field of veterinary research interest and their diagnosis, treatment and prophylaxis are of considerable importance in small animal medicine [5]. As travel restrictions within the European

\footnotetext{
*Corresponding author:

dietmar.hamel@tropa.vetmed.uni-muenchen.de

${ }^{a}$ Current Address: Merial GmbH, Kathrinenhof Research Center, Walchenseestr. 8-12, 83101 Rohrdorf, Germany
}

Union are essentially non-existent, animals are freely transferred from non-endemic regions into countries endemic for vector-borne infections and vice versa. A previous evaluation by questionnaire reported that more than $50 \%$ of 5,240 German dogs have crossed the border at least once and travelled e.g., to Italy, France and Spain [7]. Dogs originating from Central Europe can be considered as immunologically naïve to most vector-borne pathogens present in southern Europe and any sojourn to these regions sets dogs at risk of infection. However, recent studies evaluating laboratory data reported low 
seroprevalence rates $(<5.0 \%)$ against Babesia canis spp., Leishmania spp. or Ehrlichia canis in travelled dogs [8, 10]. This may be indicative for a low exposure to infected vectors during a limited stay, although no information on prophylactic measures, the time or duration of travel was given in these studies $[10,24]$. So far, no travelled dogs from Germany were tested involving the determination of a pre- and post-travel status on vector-borne infections. In this preliminary study, results on the serological, haematological and molecular biological examination of 106 dogs from Germany with sojourns into countries in the Mediterranean Basin and South-Eastern Europe are presented.

\section{Material and methods}

In the spring 2009 and 2010 veterinarians were informed by an advertisement placed in the monthly magazine of the German Veterinarian Society ("Deutsches Tierärzteblatt") about this prospective study. Interested veterinarians were provided with information on sampling time (e.g., for Knott's-Test) and intervals of sampling. Pet owners presenting their dogs for a routine pre- and post-travel check-up/consultation and willing to participate were asked to fill out questionnaires. The testing (P0) one to two weeks prior to departure aimed at attaining an overview on existing infections, the testing intervals of two to four weeks (P1), of six to eight weeks (P2) and of six months (P3) after travel to detect babesiosis, hepatozoonosis and ehrlichiosis by direct pathogen detection and/or seroconversion (at P1), the prolonged interval of up to 6 months aimed at the detection of patent filarial infections (at P2-P3) and delayed seroconversion in case of Leishmania spp.-infection (at P1-P3) [1, 2, 9, 26, 27] (Table 1). Inclusion criteria were at least one pre- and one follow-up canine EDTA-blood sample (P0 and P1) available from routine screening. In total, 287 EDTA-blood samples from 106 dogs belonging to 91 different dog owners could be evaluated. The study was in compliance with local regulations.

\section{Laboratory methods}

Giemsa-stained buffy coat smears were performed for the detection of pathogens in the blood and Knott's-Test for the detection of blood-borne microfilariae. The DiroChek ${ }^{\circledR}$ Canine/Feline Antigen Test Kit (Synbiotics Corp., Missouri, USA) was used for screening for D. immitis-antigen. DNA was extracted from $200 \mu \mathrm{l}$ EDTA-blood with the Qiagen DNA MiniKit (Qiagen, Hilden, Germany) following manufacturer's instructions. Quality and quantity were tested with a spectrophotometer (NanoDrop ${ }^{\circledR}$ ND-1000, Erlangen, Germany). Conventional PCRs were applied for the detection of Babesia spp.-, H. canis- and filarial-DNA (in case of positive Knott's-Test) according to previously published protocols [3, 11, 23]. Real-time PCRs were used for the detection of Leishmania spp.- and E. canis-DNA [15, Silaghi et al., unpublished]. Each PCR run involved a positive control and a negative control (PCR-clean water). Plasma for IFAT was collected by centrifugation of EDTA-blood samples. Antibodies against B. canis spp. and E. canis were tested applying commercial
Table 1. Pre- and post-travel screening panel for arthropod-borne infections.

\begin{tabular}{lcccc}
\hline Method & \multicolumn{4}{c}{ Timepoint of testing } \\
\cline { 2 - 5 } & P0 & P1 & P2 & P3 \\
\hline Giemsa-stained blood smear & $\times$ & $\times$ & & \\
Knott's-Test & $\times$ & $\times$ & $\times$ & $\times$ \\
Babesia canis canis-PCR & $\times$ & $\times$ & & \\
Babesia canis vogeli-PCR & $\times$ & $\times$ & & \\
Babesia gibsoni-PCR & $\times$ & $\times$ & & \\
Hepatozoon canis-PCR & $\times$ & $\times$ & & \\
Leishmania spp.-PCR & $\times$ & $\times$ & & \\
Filaria-PCR & $\times$ & $\times$ & $\times$ & $\times$ \\
Ehrlichia canis-PCR & $\times$ & $\times$ & & \\
DiroChek $®$-ELISA & $\times$ & $\times$ & $\times$ & $\times$ \\
Babesia canis-IFAT & $\times$ & $\times$ & & \\
Leishmania-IFAT & $\times$ & $\times$ & $\times$ & $\times$ \\
Ehrlichia canis-IFAT & $\times$ & $\times$ & & \\
\hline
\end{tabular}

IFAT-tests (MegaCor, Hörbranz, Austria) and an in-house Leishmania spp.-IFAT was used for the detection of antiLeishmania spp.-antibodies [13]. Titres of 1:64 were considered as seroreactive to B. canis spp. and Leishmania spp. and of 1:40 to $E$. canis.

\section{Animal data and questionnaire}

Participating pet owners were asked to fill in the provided questionnaires prior to and after travel to obtain individual animal data and information on travel destination, duration of the stay, prophylactic measures applied against arthropod vectors, on tick infestation on their dogs observed during holidays and to record any additional ectoparasiticidal treatment bought at travel destination.

\section{Results}

\section{Laboratory results}

\section{Pre-travel screening (P0)}

One hundred and six canine EDTA-blood samples were submitted for pre-travel screening in a mean of 7 days (1-47 days) prior to departure. None of the dogs was microfilaremic in Knott's-Test or positive for D. immitis-antigen in DiroChek ${ }^{\circledR}$ ELISA. All Giemsa-stained buffy coat smears were negative for parasites of the blood. Six dogs had antibodies against $B$. canis spp. $(3 \times)$, Leishmania spp. $(2 \times)$ and E. canis $(1 \times)$ in IFAT, another animal was seropositive for both $B$. canis spp.- and Leishmania spp.-antibodies (Table 2). One animal positive for B. canis spp.-antibodies was vaccinated against canine babesiosis according to information given by the owner. All seropositive animals had travelled previously with their owners.

\section{Post-travel screening (P1-P3)}

One hundred and six samples were available for the first post-travel screening between four and 373 days (mean 38 days) after return. None of the samples was positive for 
Table 2. Results of the screening for vector-borne infections in 106 travelling dogs.

\begin{tabular}{lcccc}
\hline Method & \multicolumn{5}{c}{ Timepoint of testing } \\
\cline { 2 - 5 } & $\mathrm{P} 0$ & $\mathrm{P} 1$ & $\mathrm{P} 2$ & $\mathrm{P} 3$ \\
\hline Giemsa-stained blood smear & $0 / 106$ & $0 / 106$ & & \\
Knott's-Test & $0 / 106$ & $0 / 101^{1}$ & $0 / 60^{1}$ & $0 / 16$ \\
Babesia canis canis-PCR & $0 / 106$ & $0 / 106$ & & \\
Babesia canis vogeli-PCR & $0 / 106$ & $0 / 106$ & & \\
Babesia gibsoni-PCR & $0 / 106$ & $0 / 106$ & & \\
Hepatozoon canis-PCR & $0 / 106$ & $0 / 106$ & & \\
Leishmania spp.-PCR & $0 / 106$ & $0 / 106$ & & \\
Filaria-PCR & $\mathrm{n}_{\mathrm{t} .}{ }^{2}$ & $\mathrm{n} . \mathrm{t}$. & $\mathrm{n} . \mathrm{t}$. & $\mathrm{n} . \mathrm{t}$. \\
Ehrlichia canis-PCR & $0 / 106$ & $0 / 106$ & & \\
DiroChek ${ }^{\circledR}$-ELISA & $0 / 106$ & $0 / 106$ & $0 / 61$ & $0 / 16$ \\
Babesia canis-IFAT & $4 / 106$ & $2 / 106$ & & \\
Leishmania-IFAT & $3 / 106$ & $3 / 106$ & $2 / 61$ & $1 / 16$ \\
Ehrlichia canis-IFAT & $1 / 106$ & $1 / 106$ & & \\
\hline
\end{tabular}

${ }^{1}$ Five (P1) and one (P2) blood sample(s) coagulated or of insufficient volume $(<1 \mathrm{~mL})$.

${ }^{2}$ n. t. $=$ not tested as all Knott's-Tests were negative.

vector-borne infections in direct methods. Dogs with antibodies against Leishmania spp $(3 \times)$ and one seroreactive against $E$. canis were again tested positive. In two dogs, B. canis spp. IFAT was negative. A total of 61 samples were submitted between 34 and 423 days (mean 171 days) after return for P2 screening. There were neither microfilariae nor antigen of $D$. immitis detectable. Two animals were again seropositive for antibodies against Leishmania spp. while no sample was submitted from the third seroreactive dog. Only 16 samples out of 106 were sent in for a third post-travel examination (P3) between 193 and 493 days (mean 322 days) after the return to Germany. All were negative in Knott's-Test and DiroChek ${ }^{\circledR}$-ELISA. The two samples positive in $\mathrm{P} 2$ were again seropositive for Leishmania spp.-antibodies (Table 2).

\section{Animal data}

The 44 male dogs and 62 bitches (106 dogs) in this study were between 0.5 and 14.5 years old (mean 5.1 years, standard deviation $(S D)$ 3.4). Forty-four dogs of breed (26 different breeds), 31 mixed breed dogs and 31 dogs without specified breed were enrolled. Sixteen dogs were taken abroad previously, 90 dogs had not travelled across the German border. The travel duration was given for $98 \mathrm{dogs}$ and varied between 3 and 62 days (mean 17 days, $S D$ 8.6); 14 dogs were taken abroad for up to one week, 26 between 8 and 14 days, 40 between 15 days and 3 weeks and 18 for more than 3 weeks. The main travel period in 2009 was between May and September ( 89 dogs) and between July and September in 2010 (17 dogs). The travel destinations are summarized in Table 3. Pre-travel ectoparasiticidal treatment was performed according to information given by the pet owners in 54 dogs $(51.0 \%)$

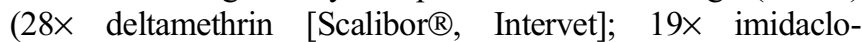
prid + permethrin $\quad[$ Advantix $\AA, \quad$ Bayer]; $3 \times$ permethrin [Exspot $\AA$, Essex]; $2 \times$ fipronil [Frontline ${ }^{\circledR}$, Merial], $1 \times$ imidacloprid [Advantage ${ }^{\circledR}$, Bayer]; $1 \times$ imidacloprid + moxidectin [Advocate $\AA$, Bayer]). Eleven dogs (10.3\%) were administered
Table 3. Travel destination by country and region.

\begin{tabular}{|c|c|c|}
\hline $\begin{array}{l}\text { Country } \\
\text { (total dogs) }\end{array}$ & $\begin{array}{l}\text { Region/ } \\
\text { province }\end{array}$ & $\begin{array}{c}\text { Number of } \\
\text { dogs }\end{array}$ \\
\hline Italy (28) & $\begin{array}{l}\text { Lazio } \\
\text { Liguria } \\
\text { Lombardia } \\
\text { Sardinia } \\
\text { South Tirol } \\
\text { Tuscany } \\
\text { Venetia } \\
\text { No information/other }\end{array}$ & $\begin{array}{l}1 \\
3 \\
5 \\
4 \\
3 \\
4 \\
5 \\
3\end{array}$ \\
\hline France (23) & $\begin{array}{l}\text { Aquitania } \\
\text { Bretagne } \\
\text { Corsica } \\
\text { Languedoc-Roussillon } \\
\text { Medoc } \\
\text { Pays de Loire } \\
\text { Provence-Alpes-Côte d'Azur } \\
\text { No information/other }\end{array}$ & $\begin{array}{l}2 \\
2 \\
1 \\
8 \\
1 \\
1 \\
7 \\
1\end{array}$ \\
\hline Croatia (17) & $\begin{array}{l}\text { Dalmatia } \\
\text { Istria } \\
\text { Primorje-Gorski County } \\
\text { No information/other }\end{array}$ & $\begin{array}{l}2 \\
7 \\
7 \\
1\end{array}$ \\
\hline Spain (17) & $\begin{array}{l}\text { Alicante } \\
\text { Balearic Islands } \\
\text { Canary Islands } \\
\text { Catalonia } \\
\text { Costa Blanca } \\
\text { Costa Brava } \\
\text { No information/other }\end{array}$ & $\begin{array}{l}1 \\
8 \\
1 \\
3 \\
2 \\
1 \\
1\end{array}$ \\
\hline Greece (7) & $\begin{array}{l}\text { Attica } \\
\text { Corfu } \\
\text { Makedonia } \\
\text { Peloponnese } \\
\text { South Aegean } \\
\text { No information/other }\end{array}$ & $\begin{array}{l}1 \\
1 \\
2 \\
1 \\
1 \\
1\end{array}$ \\
\hline Hungary (4) & $\begin{array}{l}\text { Bács-Kiskum } \\
\text { Somegy } \\
\text { Vas }\end{array}$ & $\begin{array}{l}2 \\
1 \\
1\end{array}$ \\
\hline Roundtrip (10) & Mediterranean region/Balkans & 10 \\
\hline Total & & 106 \\
\hline
\end{tabular}

other medication and no information was given in 41 (38.7\%) cases. Tick infestation was observed by the owners on 7 treated $\left(3 \times\right.$ Advantix $^{\circledR}$, Bayer; $3 \times$ Scalibor ${ }^{\circledR}$, Intervet; $1 \times$ Frontline $\AA$, Merial) and 3 untreated animals. Only 10 pet owners (11.0\%) bought additional ectoparasiticidal products $\left(5 \times\right.$; Scalibor ${ }^{\circledR}$, Intervet; 4×; Advantix ${ }^{\circledR}$, Bayer; $1 \times$ Frontline ${ }^{\circledR}$, Merial) during holidays and seven $(7.7 \%)$ pet owners bought other products.

\section{Discussion}

Canine populations from the Mediterranean Basin show high prevalence rates of vector-borne infections [24, 29]. Consequently, this topic attracted an increasing interest in veterinary medicine [5]. It is therefore noteworthy that in this study none of the dogs was infected with arthropod-borne infections due to 
the recent stay in South and South-East Europe. In total, seven dogs were seroreactive to Leishmania spp., E. canis and/or B. canis spp. at P0 prior to travel and all of these animals had been taken along on holidays previously. None of the animals were positive in Giemsa-stained buffy coat smears, Knott's-Test, DiroChek ${ }^{\circledR}$-ELISA or PCR. The overall seroprevalence rate of $6.6 \%$ in the 106 dogs is comparable to data presented in retrospective studies in dogs with travel history $[8,10]$. A publication from the Netherlands based on questionnaire and diagnostic data identified a chance of $0.23 \%$ for individual travelling dogs for attaining a Leishmania-infection [28]. In a study from the UK, dogs with travel history and positive for leishmaniosis had spent at least six months in Spain, while the average stay in the present study was only 17 days [25]. The risk of acquiring a vector-borne infection is dependent on the presence of infected vectors, their seasonal activity, the duration of exposure, the presence of suitable (reservoir-)hosts and prophylactic treatment. As this study encompassed the summer holiday period in Germany, the time of travel did not necessarily coincide with peak activity of potential vectors. While the brown dog tick is active all year round in the subtropical areas of the Mediterranean, other vectors, e.g., phlebotomine sandflies, may show bimodal activity patterns in spring and autumn or primarily in the summer month, such as mosquitoes [4, 12, 26]. This impacts the chance of a potential pathogen transmission. The low number of examined blood samples may also bias the results of the study. Moreover, the diagnosis of vector-borne infections can vary considerably depending on the applied technique as well as of the course of clinical disease [17, 18]. Nevertheless, all animals were so far considered as healthy and it can be expected that dog owners would have sent additional EDTA-blood samples of their dogs in case of impaired health status. The results are in clear contrast to laboratory data from over 15000 dogs imported into Germany published over the last ten years. Seroprevalence rates against E. canis, Leishmania spp. or B. canis spp. range from 10.6 to $18.5 \%$, cumulative prevalence rates for microfilariae and $D$. immitis-antigen are $2.6 \%$ and $1.8 \%$ in over 10000 dogs tested and $2.1 \%$ of 7500 dogs carry gamonts of $H$. canis in the blood [16, 22, 24]. Recommendations on prophylactic treatment are primarily based on data from studies in local dog populations from endemic countries $[16,29]$ Interestingly, of the $54(51.0 \%)$ prophylactically treated dogs in this study, $50(92.6 \%)$ were treated with actives (28× Scalibor ${ }^{\circledR}$, Intervet; $19 \times$ Advantix ${ }^{\circledR}$, Bayer; $3 \times$ Exspot ${ }^{\circledR}$, Essex) registered for the use against Phlebotomus spp., giving evidence that veterinarians and pet owners are aware of this important vector and rely on formulations with anti-feeding effect. It has been proven that the prevalence of vector-borne infections increases with consecutive transmission seasons and with the age of dogs $[6,14]$. A study in Italy conducted over two transmission seasons with more than 600 dogs presented an increase in Leishmania-antibody seroprevalence from $5 \%$ to more than $25 \%$ in untreated dogs while the rate in the deltamethrin-treated group remained at around 3\% [14]. Moreover, the prophylactic treatment with imidacloprid/permethrin also significantly reduced the risk of infection in treated dogs exposed to high infection pressure [19-21]. Further studies should evaluate the impact of repeated travel in dogs to assess a cumulative risk for infection.

\section{Conclusion}

These first preliminary results on vector-borne infections in travelled dogs present evidence for a low individual risk for infection during a single limited stay abroad. None of the prophylactically treated as well as untreated dogs attained an infection during the average stay of 17 days. Future studies should evaluate the impact on repeated sojourns in a larger cohort of animals.

Acknowledgements. The authors express their gratitude to Andrea Mihalkov and Ute Maurer for superb technical assistance. The authors would like to acknowledge Dr. Markus Edingloh and Dr. Stefan Pachnicke and the financial support of Bayer Animal Health, Leverkusen, Germany.

Competing interests. The authors declare no competing interests. The study ended in 2011. The first author is currently employed at Merial since 2012.

\section{References}

1. Alvar J, Canavate C, Molina R, Moreno J, Nieto J. 2004. Canine leishmaniasis. Advances in Parasitology, 57, 1-88.

2. Baneth G, Samish M, Shkap V. 2007. Life cycle of Hepatozoon canis (Apicomplexa: Adeleorina: Hepatozoidae) in the tick Rhipicephalus sanguineus and domestic dog (Canis familiaris). Journal of Parasitology, 93, 283-299.

3. Birkenheuer AJ, Levy MG, Breitschwerdt EB. 2003. Development and evaluation of a seminested PCR for detection and differentiation of Babesia gibsoni (Asian genotype) and B. canis DNA in canine blood samples. Journal of Clinical Microbiology, 41, 4172-4177.

4. Dantas-Torres F. 2010. Biology and ecology of the brown dog tick, Rhipicephalus sanguineus. Parasites \& Vectors, 3, 26.

5. Deplazes P, Staebler S, Gottstein B. 2006. Reisemedizin parasitärer Erkrankungen des Hundes. Schweizer Archiv für Tierheilkunde, 148, 447-461.

6. Foglia Manzillo V, Oliva G, Pagano A, Manna L, Maroli M, Gradoni L. 2006. Deltamethrin-impregnated collars for the control of canine leishmaniasis: evaluation of the protective effect and influence on the clinical outcome of Leishmania infection in kennelled stray dogs. Veterinary Parasitology, 142, $142-145$.

7. Glaser B, Gothe R. 1998. Hundetourismus und - import: eine Umfrage in Deutschland zu Ausmaß sowie Spektrum und Präferenz der Aufenthalts- bzw. Herkunftsländer. Tierärztliche Praxis, 26, 197-202.

8. Hamel D, Röhrig E, Pfister K. 2011. Canine vector-borne disease in travelled dogs in Germany - A retrospective evaluation of laboratory data from the years 2004-2008. Veterinary Parasitology, 181, 31-36.

9. Harrus S, Waner T. 2011. Diagnosis of canine monocytotropic ehrlichiosis (Ehrlichia canis): an overview. Veterinary Journal, 187, 292-296.

10. Hirsch N, Pantchev N. 2008. Occurrence of the travel diseases leishmaniosis, ehrlichiosis, babesiosis and dirofilariosis in dogs living in Germany. Kleintierpraxis, 53, 154-165.

11. Inokuma H, Okuda M, Ohno K, Shimoda K, Onishi T. 2002. Analysis of the 18S rRNA gene sequence of a Hepatozoon detected in two Japanese dogs. Veterinary Parasitology, 106, 265-271. 
12. Killick-Kendrick R. 1999. The biology and control of phlebotomine sand flies. Clinical Dermatology, 17, 279-289.

13. Mancianti F, Falcone ML, Giannelli C, Poli A. 1995. Comparison between an enzyme-linked immunosorbent assay using a detergent-soluble Leishmania infantum antigen and indirect immunofluorescence for the diagnosis of canine leishmaniosis. Veterinary Parasitology, 59, 13-21.

14. Maroli M, Mizzon V, Siragusa C, D’Oorazi A, Gradoni L. 2001. Evidence for an impact on the incidence of canine leishmaniasis by the mass use of deltamethrin-impregnated dog collars in southern Italy. Medical and Veterinary Entomology, 15, 358-363.

15. Mary C, Faraut F, Lascombe L, Dumon H. 2004. Quantification of Leishmania infantum DNA by a real-time PCR assay with high sensitivity. Journal of Clinical Microbiology, 42, 52495255 .

16. Menn B, Lorentz S, Naucke TJ. 2010. Imported and travelling dogs as carriers of canine vector-borne pathogens in Germany. Parasites \& Vectors, 3, 34.

17. Otranto D, Dantas-Torres F, Breitschwerdt EB. 2009. Managing canine vector-borne diseases of zoonotic concern: part one. Trends in Parasitology, 25, 157-163.

18. Otranto D, Dantas-Torres F, Breitschwerdt EB. 2009. Managing canine vector-borne diseases of zoonotic concern: part two. Trends in Parasitology, 25, 228-235.

19. Otranto D, de Caprariis D, Lia RP, Tarallo V, Lorusso V, Testini G, Dantas-Torres F, Latrofa S, Diniz PP, Mencke N, Maggi RG, Breitschwerdt E, Capelli G, Stanneck D. 2010. Prevention of endemic canine vector-borne diseases using imidacloprid $10 \%$ and permethrin $50 \%$ in young dogs: a longitudinal field study. Veterinary Parasitology, 172, 323-332.

20. Otranto D, Paradies P, Lia RP, Latrofa MS, Testini G, Cantacessi C, Mencke N, Galli G, Capelli G, Stanneck D. 2007. Efficacy of a combination of $10 \%$ imidacloprid $/ 50 \%$ permethrin for the prevention of leishmaniasis in kennelled dogs in an endemic area. Veterinary Parasitology, 144, 270-278.
21. Otranto D, Paradies P, Testini G, Latrofa MS, Weigl S, Cantacessi C, Mencke N, de Caprariis D, Parisi A, Capelli G, Stanneck D. 2008. Application of $10 \%$ imidacloprid $/ 50 \%$ permethrin to prevent Ehrlichia canis exposure in dogs under natural conditions. Veterinary Parasitology, 153, 320 328.

22. Pantchev N, Etzold M, Daugschies A, Dyachenko V. 2010. Diagnosis of imported canine filarial infections in Germany 2008-2010. Parasitology Research, 109(Supplement 1), 61-76.

23. Rishniw M, Barr SC, Simpson KW, Frongillo MF, Franz M, Dominguez Alpizar JL. 2006. Discrimination between six species of canine microfilariae by a single polymerase chain reaction. Veterinary Parasitology, 135, 303-314.

24. Röhrig E, Hamel D, Pfister K. 2011. Retrospective evaluation of laboratory data on canine vector-borne infections from the years 2004-2008. Berliner und Münchener Tierärztliche Wochenschrift, 124, 411-418.

25. Shaw SE, Langton DA, Hillman TJ. 2009. Canine leishmaniosis in the United Kingdom: a zoonotic disease waiting for a vector? Veterinary Parasitology, 163, 281-285.

26. Simón F, Siles-Lucas M, Morchón R, González-Miguel J, Mellado I, Carretón E, Montoya-Alonso JA. 2012. Human and animal dirofilariasis: the emergence of a zoonotic mosaic. Clinical Microbiology Reviews, 25, 507-544.

27. Taboada J, 1998. Babesiosis, in Infectious Diseases of the Dog and Cat, 2nd edn. Greene CE, Editor. Saunders: Philadelphia. p. 473-481.

28. Teske E, van Knapen F, Beijer EG, Slappendel RJ. 2002. Risk of infection with Leishmania spp. in the canine population in the Netherlands. Acta Veterinaria Scandinavia, 43, 195-201.

29. Trotz-Williams LA, Trees AJ. 2003. Systematic review of the distribution of the major vector-borne parasitic infections in dogs and cats in Europe. Veterinary Record, 152, 97-105.

Cite this article as: Hamel D, Silaghi C \& Pfister K: Arthropod-borne infections in travelled dogs in Europe. Parasite, $2013,20,9$.

Reviews, articles and short notes may be submitted. Fields include, but are not limited to: general, medical and veterinary parasitology; morphology, including ultrastructure; parasite systematics, including entomology, acarology, helminthology and protistology, and molecular analyses; molecular biology and biochemistry; immunology of parasitic diseases; host-parasite relationships; ecology and life history of parasites; epidemiology; therapeutics; new diagnostic tools.

All papers in Parasite are published in English. Manuscripts should have a broad interest and must not have been published or submitted elsewhere. No limit is imposed on the length of manuscripts.

Parasite (open-access) continues Parasite (print and online editions, 1994-2012) and Annales de Parasitologie Humaine et Comparée (1923-1993) and is the official journal of the Société Française de Parasitologie. 